\title{
Penerapan Model Contextual Teaching and Learning Untuk Meningkatkan Aktivitas dan Hasil Belajar Siswa Kelas V Tema Peristiwa Dalam Kehidupan di SD Muhammadiyah 1 Jember
}

\author{
Lutfi Muthoharoh, Yayuk Mardiati, Chumi Zahroul Fitriyah \\ Universitas Jember (UNEJ), \\ Jln. Kalimantan 37, Jember 68121 \\ E-mail: lutfixiipa1@gmail.com
}

\begin{abstract}
Abstrak
Penelitian ini bertujuan untuk meningkatkan aktivitas dan hasil belajar kelas V C pada tema 7 Peristiwa dalam Kehidupan Peristiwa Kebangsaan Masa Penjajahan, subtema 1, pembelajaran 4 di SD Muhammadiyah 1 Jember. Penelitian ini merupakan penelitian tindakan kelas. Subjek penelitian ini adalah siswa kelas V C SD Muhammadiyah 1 Jember yang berjumlah 31 siswa. Teknik pengumpulan data menggunakan wawancara, observasi, dokumentasi, dan tes. Berdasarkan hasil observasi aktivitas belajar secara klasikal pada prasiklus 52,25\% (kategori cukup), meningkat menjadi 63,35\% (kategori cukup) pada siklus I, dan meningkat lagi menjadi 74,7\% (kategori aktif) pada siklus II. Sedangkan untuk hasil belajar secara klasikal pada prasiklus $67,93 \%$ (kategori cukup), meningkat menjadi $81,12 \%$ (kategori sangat baik) pada siklus I, dan meningkat lagi menjadi 89,35\% (kategori sangat baik) pada siklus II. Berdasarkan uraian di atas, maka dapat disimpulkan bahwa penerapan model Contextual Teaching and Learning pada tema 7 Peristiwa dalam Kehidupan Peristiwa Kebangsaan Masa Penjajahan dapat meningkatkan aktivitâs dan hasil belajar siswa kelas V C SD Muhammadiyah 1 Jember.
\end{abstract}

Kata Kunci: model contextual teaching and learning, aktivitas, hasil belajar siswa

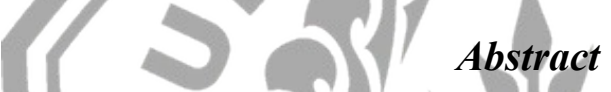

This research aims to improve the activities and learning outcomes of 5th grade students on the theme "Events in Life" subtheme 1 "Events Nationaly of Colonialism", learning 4 in elementary school Muhammadiyah 1 Jember. This research is a classroom action research. The subject of this study were 31 V C grade students of Muhammadiyah Elementary School 1 Jember. Method of data collection uses interviews, observation, documentation, and test. Based on observations of students' activities classically at the pre-cycle was 52,25\% (enough category), increased to $63,35 \%$ (enough category) in the first cycle, and increased again to 74,7\% (active category) in cycle II. Meanwhile result of learning achievement classically at the pre-cycle was $67,93 \%$ (enough category), increased to $81,12 \%$ (very good category) in the first cycle, and increased again to $89,35 \%$ (very good category) in cycle II. Based on the result above, it can be concluded that the application of Contextual Teaching and Learning model with the theme "Events in Life" sub-theme 1 "Events Nationaly of Colonialism" learning 4, can improve students' activities and learning outcomes of V C graders Muhammadiyah Elementary School 1 Jember.

Keywords : contextual teaching and learning model, students' activities, learning outcomes

\section{Pendahuluan}

Pendidikan merupakan faktor utama dalam pembentukan pribadi manusia. Menyadari hal tersebut pemerintah sangat serius dalam menangani pendidikan dan berusaha untuk terus meningkatkan mutu pendidikan, sebab dengan adanya sistem pendidikan yang baik diharapkan muncul generasi bangsa yang berkualitas dan mampu mengadakan perubahan yang kearah yang baik dalam kehidupan bermasyarakat berbangsa dan bernegara. Sistem Pendidikan Nasional ditetapkan pada Peraturan Pemerintah Republik Indonesia No. 32 Tahun 2013 Tentang Perubahan Atas Peraturan Pemerintah Republik Indonesia No 19 Tahun 2005 yang telah menggariskan kriteria minimal tentang sistem pendidikan diseluruh wilayah hukum Negara Kesatuan Republik Indonesia agar dapat meningkatkan mutu pendidikan [1]. Salah satu upaya untuk memperbaiki mutu pendidikan yaitu dengan menerapkan kurikulum yang konsisten, dinamis, dan terpadu serta sesuai Badan Standar Pendidikan Nasional (BSNP). Kurikulum menurut UU No. 20 Tahun 2003 merupakan seperangkat rencana dan pengaturan mengenai tujuan, isi, dan bahan pelajaran serta cara yang digunakan sebagai pedoman penyelenggaraan kegiatan pembelajaran untuk mencapai tujuan pendidikan tertentu.

Kurikulum yang sekarang diterapkan di Indonesia yaitu kurikulum 2013, di- mana kurikulum ini memiliki rancangan implementasi pembelajaran abad 21 untuk menyikapi tuntutan zaman yang semakin kompetitif yang menekankan pada Penguatan Pendidikan Karakter (PPK), kemampuan literasi, keterampilan 4C (Communication, Collaborative, Critical thinking and Problem solving, Creativity and Innovation), dan HOTS (High Order Thinking Skill) yang diimplementasikan mulai dari tingkat pendidikan dasar. 
Penerapan kurikulum 2013 berbasis pada kompetensi spiritual, sikap, pengetahuan, dan keterampilan yang diharapkan mampu meningkatkan pengetahuan dan nilainilai karakter pada diri siswa.

Komponen di dalam kurikulum 2013 yaitu tujuan, isi, metode atau strategi, dan evaluasi. Berdasarkan Permendikbud No.24 tahun 2016 tujuan kurikulum 2013 yaitu, untuk mempersiapkan sumber daya manusia Indonesia agar memiliki kemampuan hidup sebagai pribadi dan warga negara yang beriman, produktif, kreatif, dan inovatif serta mampu berkontribusi dalam kehidupan bermasyarakat berbangsa dan bernegara. Oleh karena itu, untuk meningkatkan implementasi kurikulum 2013 diperlukan guru yang dapat merancang dan mengemas pembelajaran secara efektif, bermakna, sesuai kebutuhan, berkarakteristik serta sesuai dengan kompetensi masa depan.

Kurikulum 2013 merupakan kurikulum yang mulai diterapkan pada tahun 2013. Kurikulum 2013 mengalami revisi seiring dengan adanya revisi kompetensi inti dan kompetensi dasar. Revisi kompetensi inti dan kompetensi dasar sudah disajikan dalam Permendikbud Nomor 24 tahun 2016. Pembelajaran dalam kurikulum 2013 tersaji ke dalam bentuk tematik, termasuk pembelajaran pada kelas $\mathrm{V}$. Kurikulum 2013 SD dan MI menyatakan bahwa daftar tema di kelas $\mathrm{V}$ yaitu organ gerak hewan dan manusia, udara bersih bagi kesehatan, makanan sehat, sehat itu penting, ekosistem, panas dan perpindahannya, peristiwa/dalam kehidupan, lingkungan sahabat kita, dan benda-benda di sekitar kita. Tema yang akan diteliti dalam penelitian ini yaitu peristiwa dalam kehidupan. Tema peristiwa dalam kehidupan subtema peristiwa kebangsaan masa penjajahan membahas materi tentang informasi penting dari teks narasi, keberagaman budaya masyarakat, dan mengidentifikasi faktor-faktor penting penyebab penjajahan bangsa Indonesia dan upaya untuk mempertahankan kedaulatannya.

Hasil wawancara terhadap guru kelas $V \mathrm{C}$ di SD Muhammadiyah 1 Jember diketahui bahwa guru pada proses pembelajaran sudah menerapkan kurikulum 2013 dengan pendekatan saintifik, namun implementasi dalam kegiatan pembelajarannya masih belum berjalan secara optimal. Salah satunya yaitu dalam kegiatan diskusi secara berkelompok, ada beberapa anak yang aktif dan ada beberapa yang hanya terlihat diam Hal ini menunjukkan pemilihan serta penggunaan model dan strategi pembelajaran yang kurang variatif. Penerapan pendekatan saintifik meliputi mengamati, menanya, mencoba (mengumpulkan informasi atau mengeksplorasi), mengasosiasikan atau mengelola informasi, dan mengkomunikasikan [2]. Pada proses pembelajaran dengan pendekatan saintifik, masih banyak siswa yang menemui kendala berupa kurangnya pemahaman terhadap masalah yang disajikan sehingga siswa belum mampu mengasosiakan atau mengelola informasi dengan baik. Selain itu, metode yang digunakan guru meliputi ceramah, tanya jawab, dan penugasan belum dapat menjadikan pembelajaran berpusat pada siswa (student centered).

Berdasarkan hasil observasi sebelum tindakan, aktivitas belajar siswa berada dalam kategori cukup. Hal tersebut dibuktikan dari data lembar observasi aktivitas belajar siswa yang dibuat sesuai dengan kebutuhan penelitian pada siswa kelas SD Muhammadiyah 1 Jember.
Data yang diperoleh dari hasil observasi menunjukkan bahwa dari 31 siswa, terdapat 6 siswa $(19,35 \%)$ dengan kategori aktivitas tinggi, 18 siswa $(58,06 \%)$ dengan kategori aktivitas cukup, dan sisanya 7 siswa $(22,58 \%)$ termasuk kategori aktivitas belajar kurang. Data hasil belajar diperoleh dari data dokumentasi nilai ulangan harian, 5 dari 31 jumlah siswa di kelas (15 siswa laki-laki dan 16 siswa perempuan) terlihat bahwa 8 siswa (30,09\%) tuntas mencapai KKM dengan kategori sangat baik, 8 siswa (30,09\%) dengan kategori baik, 5 siswa (16,12\%) dengan kategori cukup baik, 9 siswa $(29,03 \%)$ dengan kategori kurang baik, dan 1 siswa $(3,22 \%)$ dengan kategori sangat kurang baik.

Penerapan kurikulum 2013 agar sesuai dengan tujuan pendidikan harus meningkatkan kompetensi pedagogik guru karena guru memegang peranan penting dalam menciptakan kegiatan belajar di dalam kelas. Supaya proses pembelajaran di kelas memberikan makna belajar maka guru dituntut kreatif dalam merancang pembelajaran guna meningkatkan kualitas belajar siswa. Pembelajaran yang bermakna memerlukan faktor yang mendukung diantaranya yaitu model pembelajaran yang digunakan harus sesuai dengan kurikulum 2013. Model pembelajaran meliputi segala aspek dălam kegiatan pembelajaran yang dilakukan oleh guru baik secara langsung maupun tidak langsung oleh guru. Salah satu model pembelajaran yang sesuai dengan penerapan kurikulum 2013 adalah model pembelajaran kontekstual (Contextual Teaching and Learning).

Model pembelajaran kontekstual (Contextual Teaching and Learning) adalah pembelajaran yang mengaitkan materi yang dipelajari dengan kehidupan nyata siswa sehari-hari baik dalam lingkungan, keluarga, sekolah, masyarakat maupun warga negara dengan tujuan untuk menemukan makna materi tersebut dalam kehidupan [3]. Penggunaan model pembelajaran kontekstual dirancang sebagai salah satu alternatif pemecahan dalam pembelajaran. Model ini dianggap efektif dalam menemukan korelasi atau hubungan bermakna antara berpikir abstark dan aplikasinya pada konteks dunia nyata. Jadi dalam akivitas pembelajaran, siswa dibimbing untuk mengaplikasikan pengetahuan awalnya secara nyata agar pengetahuan tersebut nantinya dapat bermanfaat dalam kehidupan siswa.

Fakta tersebut menunjukkan bahwa aktivitas dan hasil belajar siswa masih kurang optimal. Hal ini kemungkinan besar disebabkan karena metode pembelajaran yang digunakan kurang menarik perhatian dan mendorong siswa untuk belajar. Guru merupakan fasilitator dan motivator dalam proses pembelajaran. Apabila guru masih dominan memberikan pelajaran kepada siswanya maka siswa akan menjadi pasif selanjutnya mereka akan merasakan bosan dan tidak nyaman. Oleh sebab itu, guru harus bisa menjadikan siswa lebih aktif di dalam kelas. Upaya untuk meningkatkan aktivitas dan hasil belajar maka perlu dilakukan dengan memilih metode pembelajaran kontekstual (CTL). Metode ini diharapkan dapat membantu guru mengaitkan materi pembelajaran dan melaksanakan kerja sama di rumah dan di sekolah. Melalui metode ini siswa akan menemukan sendiri materi yang mereka pelajari dan secara otomatis mereka mengenal langsung konsep yang dipelajari. 
Berdasarkan uraian latar belakang di atas, maka perlu Penelitian Tindakan Kelas (PTK) dengan judul "Penerapan Model Contextual Teaching and Learning untuk Meningkatkan Aktivitas dan Hasil Belajar Siswa Kelas V Tema Peristiwa dalam Kehidupan di SD Muhammadiyah 1 Jember".

\section{Metode Penelitian}

Jenis penelitian yang digunkan dalam penelitian ini adalah Penelitian Tidakan Kelas (PTK) dengan rancangan model penelitian skema Hopkins yang terdiri dari 4 tahap, yaitu: (1) perencanaan, (2) pelaksanaan tindakan, (3) pengamatan/observasi, dan (4) refleksi [4]. Penelitian ini dilaksanakan dalam dua siklus dan masing-masing siklus terdiri atas satu pertemuan. Analisis data yang digunakan dalam penelitian ini adalah analisis data deskriptif kualitatif. Subjek penelitian ini adalah siswa kelas V C SD Muhammadiyah 1 Jember. Adapun jumlah subjek penelitian adalah 31 siswa dengan jumlah siswa putra sebanyak 15 siswa dan jumlah siswa putri sebanyak 16 siswa. Waktu penelitian pada semester genap tahun ajaran 2018/2019. Metode yang digunakan untuk pengumpulan data dalam penelitian ini adalah metode wawancara, observasi, dokumentasi, dan tes.

Analisis data yang dilakukan untuk rumusan masalah pada penelitian ini adalah

1. Peningkatan aktivitas belajar siswa dengan menerapkan model pembelajaran Contextual Teaching and Learning (CTL) dihitung dengan rumus :

$$
P a=\frac{A}{N} \times 100
$$

Keterangan:

$\mathrm{Pa}=$ Persentase aktivitas siswa

$\mathrm{A}=$ Jumlah skor aktivitas siswa

$\mathrm{N}=$ Jumlah skor aktivitas maksimal

Tabel 1. Kriteria Aktivitas Belajar Siswa

\begin{tabular}{|l|c|}
\hline Kriteria Aktivitas Belajar & Rentangan Skor Aktivitas \\
\hline Sangat aktif & $80-100$ \\
\hline Aktif & $61-80$ \\
\hline Cukup Aktif & $41-60$ \\
\hline Kurang Aktif & $21-40$ \\
\hline Sangat Kurang Aktif & $0-20$ \\
\hline
\end{tabular}

Dimodifikasi dari Masyhud, 2016: 357 [5]

2. Peningkatan hasil belajar siswa dengan menerapkan model pembelajaran Contextual Teaching and Learning (CTL) dihitung dengan rumus :

$$
P=\frac{n}{N} x 100
$$

Keterangan:

$\mathrm{P}=$ Presentase hasil belajar siswa

$\mathrm{n}=$ Jumlah siswa dengan hasil belajar $\geq 75$

$\mathrm{N}=$ Jumlah siswa keseluruhan

Persentase hasil belajar siswa secara klasikal dihitung dengan menggunakan rumus :

$$
P k=\frac{S r t k}{S i k} \times 100
$$

Keterangan:

$\mathrm{Pk}$ : hasil belajar klasikal

Srtk : skor tercapai oleh seluruh siswa dalam kelas

Sik : skor maksimal yang dapat dicapai oleh seluruh siswa dalam kelas

Tabel 2. Kriteria Hasil Belajar Siswa

\begin{tabular}{|l|c|}
\hline Kriteria Hasil Belajar & Rentangan Skor Hasil \\
\hline Sangat aktif & $80-100$ \\
\hline Aktif & $61-80$ \\
\hline Cukup Aktif & $41-60$ \\
\hline Kurang Aktif & $21-40$ \\
\hline Sangat Kurang Aktif & $0-20$ \\
\hline \multicolumn{2}{|c|}{ Dimodifikasi dari Masyhud, 2016: 354 [5] }
\end{tabular}

\section{Hasil dan Pembahasan}

Penelitian ini merupakan penelitian tindakan kelas yang bertujuan untuk meningkatkan aktivitas dan hasil belajar siswa melalui penerapan model Contextual Teaching and Learning. Tindakan pendahuluan yang dilakukan sebelum pelaksanaan tindakan menggunakan model Contextual Teaching and Learning adalah observasi, wawancara, dan dokumentasi. Berdasarkan tindakan pendahuluan tersebut, diperoleh informasi bahwa hasil belajar siswa dalam/kategori cukup. Guru sudah menerapkan pendekatan saintifik, namun tidak divariasikan dengan model-model pembelajaran sehingga kegiatan pembelajaran belum berpusat pada siswa (student center).

Hasil dari kegiatan observasi, ditemukan masalahmasalah lain yang timbul dari siswa dalam proses pembelajaran, antara lain : (1) masih adanya beberapa siswa yang ramai, (2) kurangnya keberanian siswa dalam mengemukakan pendapat, (3) kurangnya kemampuan siswa dalam bertanya, (4) dalam kegiatan diskusi kelompok, masih ada beberapa anak yang belum melaksanakan tugas masingmasing. Berdasarkan permasalahan tersebut diatas, maka dipilihlah model Contextual Teaching and Learning yang merupakan sebuah model pembelajaran yang mengaitkan materi pembelajaran dengan kehidupa nyata siswa sehari-hari baik dalam lingkungan keluarga, sekolah, masyarakat, maupun warga negara dengan tujuan untuk menemukan makna materi tersebut dalam kehidupan. Pelaksanaan pembelajaran Contextual Teaching and Learning terdiri dari tujuh tahapan, yaitu: (1) constructivism; (2) questionng; (3) inquiry; (4) learning community;(5) modelling; (6) reflection; (7) authentic assessment.

Aktivitas belajar siswa berdasarkan observasi secara klasikal pada prasiklus dapat diketahui masih dalam kategori cukup dengan persentase $52,25 \%$ sehingga masih perlu ditingkatkan lagi pada siklus I. Setelah dilakukan siklus I, maka diperoleh persentase aktivitas belajar siswa klasikal sebesar $63,35 \%$. Artinya telah terjadi peningkatan presentase aktivitas belajar siswa secara klasikal dari pra siklus ke siklus I sebesar 11,1\%. Berdasarkan hasil analisis tersebut, maka pembelajaran dilanjutkan pada siklus II untuk lebih 
meningkatkan aktivitas belajar siswa. Setelah dilaksanakan siklus II sesuai dengan revisi pada siklus I, maka diperoleh presentase aktivitas belajar siswa secara klasikal sebesar $74,7 \%$ (kategori aktif). Artinya telah terjadi peningkatan presentase aktivitas belajar secara klasikal dari siklus I ke siklus II sebesar $11,35 \%$, sehingga rata-rata kenaikan skor aktivitas belajar siswa secara klasikal dari pra siklus hingga siklus II adalah sebesar 22,45\%. Sedangkan untuk hasil belajar secara klasikal pada prasiklus sebesar $67,93 \%$ dengan kategori cukup sehingga perlu ditingkatkan lagi pada siklus I. Setelah pelaksanaan siklus I, diperoleh persentase hasil belajar klasikal sebesar $81,12 \%$. Artinya telah terjadi peningkatan persentase hasil belajar siswa klasikal dari prasiklus ke siklus I sebesar 13,19\%. Berdasarkan hasil analisis tersebut, maka pembelajaran dilanjutkan pada siklus II untuk lebih meningkatkan hasil belajar siswa. Setelah dilaksanakan siklus II sesuai dengan revisi pada siklus I, maka diperoleh presentase hasil belajar siswa secara klasikal sebesar 89,35\% (kategori sangat baik). Artinya telah terjadi peningkatan presentase hasil belajar secara klasikal dari siklus I ke siklus II sebesar 8,23\%, sehingga rata-rata kenaikan skor hasil belajar siswa secara klasikal dari pra siklus hingga siklus II adalah sebesar $21,42 \%$.

Aktivitas belajar siswa berdasarkan observasi secara klasikal pada pra siklus dapat diketahui bahwa presentase tertinggi aktivitas belajar kategori cukup dengan persentase $52,25 \%$. Aktivitas belajar siswa pada kategori sangat aktif sebesar 19,35\%, kategori aktif $0 \%$, kategori cukup aktif $58,06 \%$, kategori kurang aktif $22,59 \%$, dan kategori sangat kurang aktif $0 \%$. Sedangkan untuk hasil belajar siswa berdasarkan tes secara klasikal pada pra siklus dapat diketahui bahwa presentase tertinggi hasil belajar kategori cukup dengan persentase $67,93 \%$. Hasil belajar siswa pada kategori sangat baik sebesar 25,8\%, kategori baik 25,8\%, kategori cukup baik $16,12 \%$, kategori kurang baik $29,03 \%$, dan kategori sangat kurang baik 3,25\%. Berdasarkan hasil analisis data hasil belajar siswa yang telah diuraikan diatas, maka pembelajaran akan dilanjutkan pada siklus I dengan perbaikan yang harus dilakukan agaraktivitas dan hasil belajar siswa dapat lebih meningkat.

Setelah dilakukan tindakan pada siklus I, presentase aktivitas belajar siswa ada pada kategori cukup, yakni $63,35 \%$. Artinya sebagaian besar aktivitas belajar siswa berada dalam kategori cukup. Aktivitas belajar siswa pada kategori sangat aktif sebesar 19,35\%, kategori aktif sebesar 58,06\%, kategori cukup aktif 22,59\%, kategori kurang aktif $0 \%$, dan kategori sangat kurang aktif $0 \%$. Sedangkan untuk persentase hasil belajar siswa ada pada kategori sangat baik, yaitu $81,12 \%$. Artinya sebagian besar hasil belajar siswa berada dalam kategori sangan baik. Hasil belajar siswa pada kategori sangat baik sebesar 61,29\%, kategori baik 29,03\%, kategori cukup baik 3,22\%, kategori kurang baik $6,46 \%$, dan kategori sangat kurang baik $0 \%$.

Berdasarkan hasil analisis data aktivitas dan hasil belajar siswa yang telah diuraikan diatas, maka pembelajaran akan dilanjutkan pada siklus II dengan perbaikan yang harus dilakukan agar lebih meningkat. Aktivitas dan hasil belajar siswa pada siklus II sudah semakin meningkat. Hal tersebut ditinjau dari bertambahnya presentase aktivitas belajar siswa yang termasuk dalam kategori aktif, yakni dari presentase
$63,35 \%$ (siklus I), pada siklus II meningkat menjadi 74,7\% (kategori aktif). Pada persentase hasil belajar juga terdapat peningkatan dari presentase $81,12 \%$ (siklus I) menjadi $89,35 \%$.

Berdasarkan uraian di atas dapat disimpulkan bahwa penerapan model Contextual Teaching and Learning dalam pembelajaran tema Peristiwa dalam Kehidupan Peristiwa Kebangsaan Masa Penjajahan, subtema 1, pembelajaran 4 di kelas V C SD Muhammadiyah 1 Jember dapat meningkatkan aktivitas dan hasil belajar.

\section{Kesimpulan dan Saran}

\section{Kesimpulan}

Berdasarkan hasil analisis data dan pembahasan yang diuraikan pada bab sebelumnya, maka diperoleh kesimpulan bahwa penerapan model Contextual Teaching and Learning dalam pembelajaran tema Peristiwa dalam Kehidupan Peristiwa Kebangsaan Masa Penjajahan, subtema 1, pembelajaran 4 di kelas V C SD Muhammadiyah 1 Jember dilaksanakan dengan baik sesuai dengan Rencana Pelaksanaan Pembelajaran (RPP) yang telah disusun sebelumnya, sehingga dapat meningkatkan aktivitas dan hasil belajar siswa. Hal ini dapat diamati dari persentase aktivitas belajar siswa prasiklus sebesar $52,25 \%$ kategori sedang, memingkat menjadi $63,35 \%$ dengan kategori cukup pada siklus I, dan meningkat lagi menjadi $74,7 \%$ pada siklus II. Sedangkan persentase hasil belajar prasiklus sebesar $67,93 \%$ dengan kategori cukup, meningkat menjadi $81,12 \%$ dengan kategori sangat baik pada siklus I, dan meningkat lagi menjadi 89,35\% dengan kategori sangat baik pada siklus II.

\section{Saran}

Berdasarkan kesimpulan diatas, saran dalam penelitian ini sebagai berikut:

- bagi peneliti, diharapkan dapat menambah pengetahuan dan dijadikan masukan dalam melaksanakaan penelitian lain dengan subjek dan variabel yang berbeda.

- bagi guru, diharapkan model Contextual Teaching and Learning dapat dijadikan alternatif untuk melaksanakan kegiatan pembelajaran.

- bagi kepala sekolah, diharapkan melakukan pelatihan untuk membina guru tentang CTL, sehingga guru dapat menerapkannya dalam kelas.

- bagi peneliti lain, disarankan agar merujuk hasil penelitian ini untuk penelitian lain yang sejenis.

\section{Daftar Pustaka}

[1] Kemendikbud. 2016. Peraturan Menteri Pendidikan dan Kebudayaan Nomor 24 Tahun 2016 Tentang erangka Dasar Dan Struktur Kurikulum Sekolah Dasar/Madrasah Ibtidaiyah. Jakarta: Kemendikbud

[2] Kemdikbud. 2016. Salinan Permendikbud Nomor 22 tahun 2016 Tentang Standar Proses Pendidikan Dasar dan Menengah. Jakarta: Kemdikbud.

[3] Komalasari, K. 2010. Pembelajaran Kontekstual: Konsep dan Aplikasi. Refika Aditama. Bandung.

[4] Arikunto.(2015). Penelitian Tindakan Kelas Edisi Revisi.Jakarta:Rineka Cipta.

[5] Masyhud, S. 2016. Metode Penelitian Pendidikan. Jember. Lembaga Pengembangan Manajemen dan Profesi Kependidikan. 